\title{
Techno-species in the Becoming Towards a Relational Ontology of Multi-species Assemblages (ROMA)
}

\author{
Tanja Kubes (D) Thomas Reinhardt
}

Received: 13 September 2020 / Accepted: 6 November 2021 / Published online: 13 December 2021

(C) The Author(s), under exclusive licence to Springer Nature B.V. 2021

\begin{abstract}
Robots equipped with artificial intelligence pose a huge challenge to traditional ontological differentiations between the spheres of the human and the non-human. Drawing mainly from neo-animistic and perspectivist approaches in anthropology and science and technology studies, the paper explores the potential of new forms of interconnectedness and rhizomatic entanglements between humans and a world transcending the boundaries between species and material spheres. We argue that intelligent robots meet virtually all criteria Western biology came up with to define 'life' and that it ultimately makes sense to recognize them as a new species that is part of our social universe. Contrasting dualistic concepts of man and nature with a monistic approach, we show that traditional properties of life (agency, self-replication, etc.) may apply to artefacts and that, once we accept the idea that social relationships are ultimately open connections to matter of any kind, the seemingly strict boundaries between species and material spheres can no longer be sustained. Instead, we propose to include 'matter' and ideas into the sphere of the social as
\end{abstract}

T. Kubes $(\bowtie)$

Gender and Science Studies in Physics, FU Berlin, Department of Physics, Arnimallee 14, 14195 Berlin, Germany

e-mail: tanja.kubes@fu-berlin.de

T. Reinhardt

Institute for Social and Cultural Anthropology, LMU

Munich, Oettingenstr. 67, 80538 Munich, Germany

e-mail: thomas.reinhardt@ethnologie.lmu.de agents in their own right to form a relational ontology of multi-species assemblages (ROMA).

Keywords Science and technology studies . Ontological turn · Anthropology beyond the human . Critical posthumanism $\cdot$ Naturecultures $\cdot$ Social robots

\section{Introduction}

Humankind's ancient dream of creating life resonates throughout the myths and stories of many societies. Advances in science and engineering-specifically the construction of robots equipped with artificial intelligence-have brought us a good deal closer to making this fantasy a reality. The question no longer seems to be whether it will one day be possible to breathe life into matter, but rather how we shall cope with it conceptually. Can life actually be created from something inanimate? Or to put it differently: What are the preconditions for attributing 'life' to man-made artefacts, and how should ontology and anthropology deal with this blurring of once clear-cut categories? One major problem when addressing questions like these is that there is always a subtext suggesting not just an extension of the concept of life but also assuming an essential isomorphism in the ways of being of humans and intelligent robots. From an ontological perspective, however, this is not a prerequisite for establishing functioning social relationships 
between the two. Sociability is not limited to humans. We are entangled in co-constitutive social relationships with our environment all the time. A second problem is that the notion of life itself is less clear than it seems. For some years now, it has become common to refer to any branch of research in the natural and engineering sciences that deals with the structures and behaviour of living organisms as 'life science'. This terminological shift, however, conceals the fact that there is no consensus on what the central designator of the term actually means: life. A look at an all too familiar 'fringe life form' may illustrate this point: There has been an ongoing controversy on whether or not viruses are alive for some decades now (with a slight inclination towards the negative). Like AI or robots, viruses, lacking a number of key characteristics widely considered necessary criteria of life (cellular structure, metabolism, etc.), technically are not 'alive'. Rather, they occupy an ontological niche somewhere "at the edge of life" [1]. This epistemological indecisiveness notwithstanding, however, they have over and again wielded an undeniable impact over our everyday lives and deeply changed the way we perceive ourselves and interact as humans. The same holds true for robots and AI.

People have reacted differently to this challenge. Throughout history, one very common strategy has been to animate the seemingly inanimate and provide it with some form of fictional agency and intentionality. The former president of the USA did just that when he called the SARS-CoV-2-virus "the invisible enemy" [2], thus shifting the focus of his corona response from handling a 'thing' towards dealing with an onslaught by a malicious aggressor. Quite obviously, the then incumbent of the White House was simply providing a vivid example of what anthropology refers to as 'old animism', the idea of "pervading life and will in nature far outside modern limits" [3] in order to make sense of the inexplicable. This form of animist theorizing usually went hand in hand with a Eurocentric overemphasis on Western achievements, placing animistic beliefs on a lower step of a made-up evolutionary ladder. Anthropologists, therefore, have dismissed the 'old animism' almost a century ago- and rightly so.

However, stripping the argument from its political content and the mental inadequacies of its producer, we may actually find some plausibility in the idea of broadening the perspective on what we call life and agency, opening it up to non-human actors (or actants) in a relational ontology of multi-species assemblages (ROMA). If an entity inhabiting "the edge of living" can force us to change our ways of life and enter into social interactions with it, could not beings conventionally thought of as 'inanimate', like robots or computers, as well? Could it be that we are entwined with the world 'around us' in ways much more complex than recognized by large parts of the humanist (and anthropocentric) discourse on humans and our role in the world? Will we, in the long run, be able to maintain the arbitrary distinction between 'us' and the rest? Or shall we, sooner or later, have to attribute agency and 'life' to nonhuman entities as well-be they organic, mechanic, or electronic in nature?

This paper explores the implications of acknowledging forms of interconnectedness and rhizomatic entanglements with a world transcending the boundaries between species and material spheres in the form of a relational ontology of multi-species assemblages (ROMA). We will argue that intelligent robots meet virtually all criteria modern biology came up with to define 'life' and that it is ultimately more useful than not to recognize them as a new species. Once we accept the idea that relationships in ROMA are open connections to matter of any kind, that they are becomings as a form of de-essentialized embodiments [4], we cannot but adopt the idea of a more comprehensive sharing of the power to act and to refuse taking any stable distinction between humans and the non-human for granted [5]. By combining approaches from science and technology studies (STS) with debates on critical post-humanism and findings from multispecies anthropology and anthropology beyond the human, we will argue that human robot interaction does in fact pave ways to hitherto unimagined forms of interconnectedness between nature- and techno-species. In the resulting fabric of ROMA, neither will strict boundaries between species be sustained [6] nor will it any longer be possible to exclude 'matter' and ideas from the field of action. Like in a Foucauldian vision, "man", as we know him/her, will be "erased, like a face drawn in sand at the edge of the sea" [7]. 


\section{Historical Backdrop}

For many centuries, Western ontology has assumed a special role for "man" in the world and took him/her as its "taken-for-granted centrepiece" [8]. Unlike other living beings or inanimate things, he/she was thought to inhabit a unique place, first, in God's plan, later, in a secularized nature. One way to define this centrality of humans has been by focussing on agency: Humans are acting on the world, while everything else is a passive object waiting to be manipulated. At best, it is believed to show traces of behaviour in simple stimulus-response patterns. This, however, must not be confused with acting (which, according to this view, requires an active, intentional subject acting according to plan). Without any doubt, this view has a lot to offer. Human impact on the Earth's geology and ecosystems cannot be seriously contested, and it certainly makes sense calling the geological epoch we live in the Anthropocene. The fact that human actions endanger our planet's ecosystem, however, does not necessarily imply that humans are the only actants in this endeavour. There are palpable limits to the human capacity to manipulate our surroundings that root not in man's insufficiency to exercise his/her powers but in the very absence of an ultimate differentiation between subjects and objects. Whether it is the rise of global temperatures, the melting of the polar caps, the slowing of the Gulf Stream, or viruses like SARS-CoV-2, in all those instances, humans eventually turn out to be just one actor in a complex network of interconnected actants.

This thought is not entirely new. Even though Western thinking after Descartes has widely embraced the dualistic differentiation between res cogitans and res extensa, between mind and body, between substance and accidents [9], there has been a monistic counter current all along, going all the way back to pre-Socratic philosophers like Thales, Anaximander, Heraclitus, or Parmenides. Over the course of the millennia, those monistic approaches took various forms. While ancient philosophy was preoccupied with identifying the primordial matter that accounts for everything being and idealistic monists like George Berkeley were entirely disregarding the physical world, modern monistic thinking is usually traced back to the seventeenth-century
Dutch thinker Baruch de Spinoza. Spinoza's neutral monism holds that humans are not autonomous, purposeful actors having their own way no matter what but should rather be considered as the result of constant causal interactions with other humans as well as with their non-human environment (an early variant of ROMA, if we so may say). Thus, even though acknowledging an irreducible difference between extension and cogitation, between body and mind, Spinoza stresses their parallelism as just different attributes of the same underlying substance. Proposition vii of the second part of his Ethics makes this clear: "The order and connection of ideas is the same as the order and connection of things" [10]. In other words, Spinoza rejects the common hierarchization of mind and matter and redefines them as alternate modes of the same underlying principle that is differentiated in processes of attribution. This dynamic conception of body and mind inspired twentieth-century thinkers like Gilles Deleuze to develop theories of differentiation that do not depend upon an original act of creation. Rather, philosophical thinking for Deleuze starts with a difference in itself (différence en elle même [11]). Differentiation, in this view, has its cause in itself without relying on a transcendental derivation. It does not mark the relation between two items that each has a prior identity of its own. Instead, identity itself is only produced through the process of relating differentials ([11-13]). Or as Spinoza put it: "By that which is 'self-caused' I mean that of which the essence involves existence, or that of which the nature is only conceivable as existent" [10]. There is no before or outside of that which exists.

How, then, does difference originate? To explain for, in fact, any kind of differentiation, Spinoza relates to the dynamics of bodies in space which are "either in motion or at rest" and which can be distinguished with respect to their movement. Substance, as becomes clear from this definition, is not a relevant factor for differentiation [10]. Spinoza elaborates on this thought in axiom I of the corollary to proposition xiii:

All modes, wherein one body is affected by another body, follow simultaneously from the nature of the body affected and the body affecting; so that one and the same body may be 
moved in different modes, according to the difference in the nature of the bodies moving it. [10]

The key term here is of course affecting. Individual existence, for Spinoza (just as in the more contemporary adaption of his thinking in Deleuze and others), is caused by the individual's capability of affecting and being affected. Individuation, thus, is rooted in a constant flow of mutual exchanges [11] and in the concrete actualization of potentialities.

In recent decades, this idea of relational epistemologies or emerging ontologies has attracted many theorists from various backgrounds. Bruno Latour's actor network theory [14], without relying explicitly on Spinoza, follows the same route-as do Karen Barad's agential realism [5, 13], Philippe Descola's and Eduardo Viveiros de Castro's works on ontologies and perspectivism $[15,16]$, or the wider field of feminist STS [17-22]. All of them oppose the modernist dualism of mind and body and the naturalist demarcation of the realms of the human and the nonhuman in absolute terms. Instead of human actors manipulating their environment, human actions are increasingly seen as part of a complex interplay of multiple actants. Some of them 'alive' (in the classical sense of the term), many, however, inanimate.

One word of caution at this point to counter a common misunderstanding: Elevating former objects to the status of social actors or actants is not the same as anthropomorphizing them. 'Sociality' is not limited to human-human communication. On the contrary, already a superficial view on our everyday practices of interrelating with dogs, houseplants, mobile phones, computers, telephone helplines, and robocalls shows that we increasingly enter social interactions without engaging with human counterparts at all. 'Robophilosopher' Johanna Seibt identified as ontological base for such forms of asymmetric social interactions "our tendency to sociomorphize" actants [23]. Social agency, in Seibt's understanding, can be performed by a wide range of possible agents-some of them even purely fictional-without becoming less efficient. And while there are certainly fields in which social agency still very much equals human agency, in many everyday situations, we can very well do without. Pet owners, for example, usually are well aware of the fact that (lacking certain intellectual skills) their dog or cat may not love them the way another person might. The same holds true for the owners of sex robots [18, 19]. However, how we eventually respond to social situations is only partly due to its 'real' participants. Rather, what counts is, how social counterparts are inferred or projected. What matters is not how a social constellation really is but what a participant believes it to be [18]. A credible simulation may well substitute for the 'real thing' without having to be a complete functional replication of all of its aspects.

\section{Anthropological Intervention}

Back in 1988, British anthropologist Marilyn Strathern has popularized Indologist McKim Marriott's [24] concept of the "dividual" (originally designating a person as conglomerate of transferable particles that build his or her personal substance), defining a person's unity as "derived from the dividual through the halving of a pair or (...) the dissolution of a composite, multiple condition into a bounded, homogeneous state" [25]. The important point here is that, in this conception, the person is neither something given as an apriority nor is it seen as the result of an aggregation of fragments. Quite the opposite, it is believed to stem from the deconstitution of a multiplicity of potentialities. Accordingly, a person's body is not an independent, indivisible, skin-bound entity that enters into its worldly ventures, it only takes a singular form by being contrasted against other such 'wholes' that also dispose over no margins prior to the ones established in ROMA [25].

The Israeli anthropologist Nurit Bird-David further elaborates on this idea, opposing the individuation of human beings (by being conscious of other persons in themselves) to dividuating them (by focusing on how these persons relate with other persons):

This is not to say that I am conscious of the relationship with [another person] "in itself," as a thing. Rather, I am conscious of the relatedness with my interlocutor as I engage with her, attentive to what she does in relation to what I do, to how she talks and listens to me as I talk and listen to her, to what happens simultaneously and mutually to me, to her, to us. [26]

Instead of extrapolating the modernist conception of the individual self as a substance or an essence, the person here is considered as fragile, ever emerging, 
"evolving product of bundles of relationships" [27] that - and this is the decisive post-humanist twist that links the idea to our considerations from the previous chapter-are not limited to interactions with other humans.

Adapting Freud [28], one might well speak of yet another blow to the universal narcissism of men. Not only is Earth after Copernicus no longer the static centre of the universe, not only are we, after Darwin, no longer substantially different from animals or superior to them, not only is our ego, according to Freud himself, no longer master in its own house- on top of all this, there is an increasing awareness that the very idea of the individual person as a discrete entity acting upon the world may very well be an illusion. Instead, we may have to redefine our relations with our surroundings, viewing ourselves as just "knots" [29] in a complex fabric of mutual interconnectivities-neither substantially different from our environment nor the only being equipped with agency.

The question therefore needs to be addressed: Are humans 'special'? In what respect do we differ from the non-human? No matter what the answer is, it determines where and how we define our place in the world. Whether or not we are willing to accept non-human beings as vis-à-vis on an equal footing, depends on where we draw the line between humans and non-humans, between the living and the inanimate.

At first glance, there seems to be little debate on the issue. However, the easiness with which most Westerners come up with a clear-cut solution for the problem is ultimately a perfect indication of how deeply ontological assumptions are interwoven in the fabric of our thinking. Philippe Descola, in his ground-breaking book Beyond Nature and Culture [15], maintained that there are ways of delineating the spheres of the human and the non-human in ways radically different from ours. Explicitly describing his endeavour as a call for anthropology to shed its inherent dualism and become "fully monistic" [15], Descola sets out to deconstruct the binary separation between the cultural worlds of humans, on the one hand, and nature, on the other. Having done fieldwork among the Achuar for over two years, he is extremely well equipped to elaborate on the tendency of many Amazonian populations to treat some (but far from all) elements in the environment as persons "endowed with cognitive, moral and social qualities analogous to those of humans, thereby making it possible for communication and interaction between classes of beings that at first sight seem very different" [15].

Local concepts of 'person', in many Amazonian contexts, cover a wide range of life forms-with severe ontological consequences, usually referred to as 'perspectivism' in anthropological literature. The general idea here is that "animals are people, or see themselves as persons" [16]. Thus, jaguars perceive themselves as humans. Blood for them is manioc beer. Likewise, a vulture sees his feathers, claws, and beak as body decorations or tools. Jaguars see humans as peccaries, peccaries see humans as jaguars, and so on. In assuming that spirits, plants, and animals have a soul similar to the one humans are believed to have, these Amazonian cosmologies do not really "discriminate between human beings and non-human beings" [15]. What they do instead is focussing on what level of exchange is possible between individuals-no matter what sphere they belong to. Some communications are easy, and some are harder and can only be properly handled by shamans. However, there is no substantial disparity between an Achuar and the member of another Jivaro tribe or a European and, let us say, a jaguar or a peccary, that would make the latter two fundamentally different from the former.

It may be tempting to dismiss the Achuar worldview as just another exotic way of misrepresenting the 'real' relationships between culture and nature. However, can we really be sure that our naturalist ideas about the world are 'true' in a non-arbitrary sense of the term? Descola contends that any such presumption of truth is guided by cognitive and corporeal templates so deeply internalized that they form a blind spot to most auto-reflexive considerations. To shed light on this blind spot, Descola deploys a simple cross-tabulation asking for continuities and differences with regard to interiority (how does the other's internal world relate to mine?) and physicality (how does the substance the other is made of relate to mine?) [15].

This framework allows for four basic ontologies that govern collective ideas about personhood, culture, and environment: Animism (not to be confused with the 'old animism' of Edward Burnett Tylor and his contemporaries) assumes similar interiorities paired with radically different materialities. This is what Descola, Viveiros de Castro, and others described in the Amazonian context. Animals and 
plants are considered to have a soul and perceive themselves and their relation to their environment just the way man does. What makes humans different from jaguars and peccaries is not the presence or absence of a soul, the presence or absence of sociality, or the presence or absence of self-reflection, but their physical appearance - their materiality.

Naturalism - the dominant Western ontology for many hundred years now-does just the opposite and claims a radical separation of internal lives while being identical as for physicality. In fact, it is a recurring theme in Western philosophy that, regarding his/her physical composition, man is an animal like any other mammal. When it comes to interiority, however, we are elevated above nature through our mental faculties.

The cross table lists two more possibilities that Descola elaborates on (albeit to a lesser degree): Totemism, which sees continuities in both the realms of interiority and physicality, and analogism that holds that each being has a uniquely constituted interiority and physicality. Both, however, only matter for our argumentation insofar as they illustrate the possible variety of ontological positions.

\begin{tabular}{lll}
\hline & $\begin{array}{l}\text { Dissimilar in } \\
\text { physicality }\end{array}$ & Similar in physicality \\
\hline $\begin{array}{l}\text { Similar in interiority } \\
\text { Dissimilar in interiority }\end{array}$ & Animism & Totemism \\
\hline
\end{tabular}

The four basic ontologies according to Descola [15]

To be sure, Descola does not align himself with the usual suspects of critical post-humanism [5, 13, 30-33]. In fact, except for his close personal friend Bruno Latour [34], who occupies a somewhat fringe position in post-humanist debates, he does not refer to any author commonly associated with post-humanism. Still, his work provides an important backdrop to debates on future alignments of human and non-human actors. It skilfully shows that delineations between nature and culture or between humans and non-humans are in themselves a cultural thing (or a reflection of their being "situated naturecultures" [6], as Donna Haraway would have it). And what is more, it redefines animism in a way that allows for using the concept to explain the intricate entanglements of humans and animals or humans and robots as social collectives in a nondiscriminatory way by relating them to other forms of ontological differentiations that also assume similar interiorities while maintaining a radically different materiality.

In Descola's scheme, both naturalism and animism see human sociality as the prototype of how social collectives are organized. However, while naturalism reserves the privilege of sociability exclusively for humans, animism holds the door open for non-human and mixed variants of social collectives and the transgression of species boundaries through shamans (or computer scientists). We want to be careful here, not to take these ontological tendencies as non-negotiable, mutually exclusive principles. In fact, it is only all too common to switch between them according to context.

A crucial question is, however: How strong is the Western world view, in fact, entrenched in naturalism? And how stable is the Cartesian dualism separating humans from nature? In an ecological classic, American philosopher Neil Evernden gives a striking example of how fragile that basic distinction really is. Evernden describes how in the nineteenth century some physiologists adopt a routine precaution to conducting vivisections: They severe the vocal cords of the poor creature on their table to prevent it from barking or crying. Doing this, the vivisectionist of course at the same time affirms and denies the animal's 'humanity':

He was denying it in that he was able to cut the vocal cords and then pretend that the animal could feel no pain, that it was merely the machine Descartes had claimed it to be. But he was also affirming his humanity in that, had he not cut the cords, the desperate cries of the animal would have told him what he already knew, that it was a sentient, feeling being and not a machine at all. [35]

Eventually, it is the ideology of modernist dualism within a naturalist ontology that enables those scientists to detach themselves far enough from their counterpart to perform their cruel task. But this detachment does not come naturally. Only by cutting the vocal cords, the animal is actively transformed into a part of nature that can be treated at will. Its constant oozing into bios is brought to a halt, and the animal is 
reduced to the bare life of zoé [36]. This move bears all the hallmarks of a decidedly cultural act. The social relation to the animal is not just denied because of some transcendental division; it is actively shut off.

Animism with its relational ontology here offers a viable path towards a more comprehensive understanding of interspecies relationships. By addressing 'objects' in ways traditionally reserved for human interactions, it constantly generates 'hybrids' or 'quasi-objects' that transgress the modernist divide between nature and culture. The animist, rather than inhabiting a ready-made world, finds him/herself in a "world-in-formation" [37] developing in accordance with the growth of relationships. In short: "Life (...) is not an emanation but a generation of being, in a world that is not pre-ordained but incipient, forever on the verge of the actual" [ibid.]. Life, according to new animist considerations, cannot be reduced to a single origin or a singular moment of birth. It is a "complex network of reciprocal interdependence" [38], emerging at every given moment in time through the give and take of multifaceted types of communication between partners of different material qualities. Species, here, instead of being clearly delineated, context-independent genealogical types, constantly emerge as entangled agents with one another that "cross-cut the boundaries of conventional taxonomic groupings" [38]. Crossing into the realm of the inanimate, quite the same holds true for 'things' like food, stone axes, pottery, books, mathematics, or robots: They, too, emerge "within the relational contexts of the mutual involvements of people and their environments" [38] and thus may further add to our understanding of the practices that shape the "socialnatural landscape" $[39,40]$ in order to question the idea of human exceptionalism and the restricted attribution of sociality, morality, and personality rights to man alone $[6,39,41]$.

\section{Being Alive?}

Descola's ontological considerations deconstruct the absolute claim to ontological truth of naturalism, yet they still presume a central role for life in any definition of humankind. No matter where we draw the line between nature and culture or between the human and the non-human, everything that falls into the same ontological order as humans shares with us the property of 'being alive'. While, at first glance, this raises little objection, defining 'life' is much harder than it may look. Foucault has shed light on the surprising fact that up to the end of the eighteenth century, "life does not exist: only living beings" [7], which were "viewed through a grid of knowledge constituted by natural history" [7]. What Foucault refers to here, is a fundamental reorganization of Western classifications of nature around the turn of the nineteenth century. Until the eighteenth century, nature was usually thought of as being divided into three realms: "minerals, which are recognized as capable of growth, but not of movement or feeling; vegetables, which are capable of growth and susceptible to sensation; and animals, which are capable of spontaneous movement" [7]. Within this system, the paramount role of humans is guaranteed by a further subdivision in zoé ( $\zeta \omega \eta$ ) and bios (ßíos), with zoé as "bare life" coming to every living being, while bios, as related to logos ( $\lambda$ ó $\gamma \circ$ s), remains exclusively reserved for humans [36]. Lamarck, Goethe, and others, however, proposed a radically reduced partition, allowing henceforward only for two classes of bodies: "the inorganic was non-living, inanimate, inert; the organic was what breathes, feeds and reproduces" [42]. Within this dualistic logic, the fundamental distinction between $z o e ́$ and bios was retained in order to stress the preeminence of humans.

Progress in the field of artificial intelligence (AI), however, changed the rules of the game. True, AI still lacks pretty much behind the human brain when it comes to network complexity. For example, GPT3, a neutral network powered language model, while showing impressive results, relies on only (!) roughly 175 billion parameters-compared to the average human brain disposing of about 100 trillion synapses [43] and clearly lacks even the basics of semantic understanding [44]. Still, since most of us are quite content with good simulations, it has become increasingly harder to adhere to the idea of logos as something exclusively human. Traditional classifications, thus, experience a severe blurring of boundaries. We may hesitate to attribute the quality of zoé to intelligent robots-yet, they decisively share with us many of the fundamental properties of bios, thus generating the ontological paradox of 'living' without participating in bare life. It seems therefore time for a closer look on what life under the conditions of AI could 
look like. Or, more precisely, to ask how we can redefine the concept of life in order to accommodate technologically changed conditions.

'Classical' definitions of life list seven preconditions that need to be met in order for something to be called a living being: organization, homeostasis, metabolism, reproduction, growth, adaption/ evolution, and sensitivity [45]. This characterization raises a number of problems. As already stated above, viruses fail to comply with several of those requirements: they have no metabolism of their own, they need a host cell to reproduce, and-lacking a cellular structure-it does not really make sense to speak of them in terms of homeostasis. What is even worse, they seem to contest the evolutionist dogma of unilineal progression and persistently challenge taxonomic attempts to fit their origins into a unifying evolutionary tree. Because of a virus' constant 'intermingling of characteristics due to different combinations of basic modules" [1], classical approaches to classification just do not apply to viruses [ibid.]. Rather, the manifold interplays of nuclear, mitochondrial, and chloroplast genomes should be considered as forming multifaceted "phylogenetic networks" [ibid.]. Thus, in order to adequately describe the evolution of viruses, we need to move from an intrinsic definition to a process-related, relational one.

Another problem with narrow definitions of life is that they categorically exclude possible life forms outside the framework of the hitherto known. Extraterrestrial civilizations or intelligent robots, for example, cannot be accounted for by them. The SwedishAmerican physicist and cosmologist Max Tegmark, therefore, suggests a much broader concept of life, defining it simply as "a process that can retain its complexity and replicate" [45]. Since replication deals with information rather than substance, this definition of life as "a self-replicating information-processing system whose information (software) determines both its behaviour and the blueprints for its hardware" [46] would solve at least some of the problems mentioned and include viruses as well as AI. For further specification, Tegmark proposes a threefold scheme. It reminds a bit of the pre-Lamarckian triadic system, yet with a significant twist. Tegmark's classification relies on three easy questions: "Can [the system in question] survive and replicate? Can it design its software? Can it design its hardware?" [46]. "Life 1.0" is basically determined by its DNA and, throughout its life span, relies exclusively on simple stimulus-reaction patterns. It behaves, but it does not really intentionally act on its own. In a more complex mode of existence, "Life 2.0" is able to model and redesign its software, i.e. to learn. We learn to walk, to speak, to play the piano, or, if we are a dog, to sit, when the master says "sit!". We can change world views and become religious or agnostic, conservative or liberal, and so on. We might also want to include forms of self-adapting machine learning in this category, i.e. computers that, albeit starting from an original algorithm, construct their knowledge by themselves. Life 2.0 clearly is equipped with the power to act. It sets goals and pursues them-and is flexible enough to sometimes reverse them. However, except for limited modifications through workout or cosmetic surgery (and the gradual replacement of old body cells over the passing years), we are not able to fundamentally change our 'hardware'. That is left exclusively to "Life 3.0" - a form of life that does not yet exist on our planet and, for the time being, better be left as a utopian dream for transhumanists.

Nevertheless, AI certainly heads in the direction of Life 3.0. Computer programs can replicate, they can learn, and they are not restricted to a specific physical manifestation. So, why are we so hesitant to accept an intelligent robot as a ('somehow') living being? Even more so, we seem to be more willing to acknowledge the structural homology between a virus and a computer virus, the latter being thus entitled to inhabit at least the fringes of life, while continuing to consider the system it infects as a mere 'thing'. This is all the more interesting, since we do not seem to have that many difficulties conceding 'life' to beings not able to modify their software (trees, cells, bacteria, etc.).

A possible solution to this dilemma could be in focussing on the procedural aspect of life rather than on its essence. Tim Ingold, paraphrasing an argument from French philosopher Henri Bergson, calls for an emphasis on movement, or wayfaring, in defining life. If it is true that, as Bergson had it, every organism is "like an eddy cast in a flow", then the living being is not so much an object as "above all, a thoroughfare" [47, 48]. Consequently, an organism does "not so much exist as occur" (ibid.). It is instantiated "not as a bounded entity but as (...) a continual "moving around' or coming and going, as in wayfaring" [48]. This would also account for the fact that whenever we are to characterize someone, we usually refer to other persons he/she is in contact with and the things he/ 
she does or did-not to their substance (60.3\% hydrogen $25.5 \%$, oxygen $25.5 \%$, etc.). "The life of a person is the sum of his tracks", as Roy Wagner once put it: 'Being', thus, is first of all 'being in relation to' [49].

\section{Conclusion: Towards a Relational Ontology of Multi-species Assemblages (ROMA)}

Many people feel uneasy when confronted with the possibility of 'living' machines. Should a living being not be able to have a basic understanding of what it says and does [50]? Should it not dispose of an "immanent telos" [51] that elevates it over the status of an artefact serving the purposes of its constructors? Should it not be able to feel? Should it not be able to remember? Some readers may be reminded of Nietzsche's happy cows from the opening passage of his essay On the Use and Abuse of History for Life, who "do not know what yesterday and today are but leap about, eat, rest, digest, and leap again (...) enthralled by the moment and for that reason neither melancholy nor bored" [52]. Like those cows, a computer or a robot with $\mathrm{AI}$, even though equipped with virtually unlimited memory storage capacity, does not remember. That makes it hard to accept it as an 'equal'. However, to solve the problem, all we really need to do is to move on to a relational ontology of multi-species assemblages (ROMA), defining an entity's ontological status no longer through what it $i s$, but through how and what it relates to-no matter whether or not these relations cross species boundaries. A "symmetrical anthropology" [34] based on ROMA decentres humanity by exposing its latent androcentrism, sexism, and racism and substitutes it for an ontology of becoming.

Northrop Frye once wrote about the Christian mystic Jakob Böhme that his books are "like a picnic to which the author brings the words and the reader the meaning" [53]. The same could be said about the ontology of life: we are only insofar as we relate to someone or something else. Our lives certainly were nothing without 'us'-but this 'we' is always part of an assemblage with other selves. Like a virus, whose genome is in fact a highly diverse configuration of guest and host genomes, we, as persons, emerge from assemblages with things and persons outside ourselves [12]. It may be flattering to think of ourselves as autonomous subjects or, at least, as the result of purely human interactions, and modernity has often given in to the temptation to succumb to this flattery. The truth, however, is that our networks are at best partially inhabited by other humans. Many, if not most, of its knots are formed by 'inanimate' matter. Objects, therefore, already are part of any subject's 'life'. Why not move one step further and acknowledge that they themselves, effectively, can be 'alive'?

The naturalist ontology is but one way to look at the world. In fact, the interconnectedness between natural and cultural spheres is far from being exhaustively covered by drawing a strict demarcation line between the human and the rest. Humans are only 'human' insofar as we relate in humanlike ways. Likewise, the distinction between nature- and techno-species does not explain for any special role of humans in the constant interweaving of bundles of relationships. The emerging assemblages we are part of have always been hybrids of human and nonhuman actants, a multiplicity of species, rhizomatic amalgams of animate and inanimate components. If, however, it is true that man as a species is a blend of multi-species relations, how does that make us any different from, say, a social robot with AI? The latter, too, is organized, it is homeostatic and displays some kind of metabolism (if only in transforming electrical energy into heat or movement), it can grow, adapt, and evolve, and it is sensitive to environmental change-in short, it shares more characteristics of life with mammals, birds, trees, fish, and bacteria than, for example, a virus.

Maybe it is time to acknowledge that, while there was a time, when it seemed useful for the advance of our understanding of the world to conceptualize it from an anthropocentric perspective, the moment may have come, in which our face, drawn in the sand, is eventually washed away.

\section{References}

1. Rybicki E (1990) The classification of organisms at the edge of life or problems with virus systematics. S Afr J Sci 86(1990):182-186

2. Shafer J (2020) Behind Trump's strange ‘invisible enemy' rhetoric. Politico 09.04.2020. https://www.politico.com/ news/magaz ine/2020/04/09/trump-coron avirusinvisible-enemy-177894 
3. Tylor EB (1871) Primitive culture: Researches into the development of mythology, philosophy, religion, art, and custom. John Murray, London

4. Braidotti R (2001) Metamorphoses: Towards a materialist theory of becoming. Polity Press, Cambridge

5. Barad K (2007) Meeting the universe halfway: Quantum physics and the entanglement of matter and meaning. Duke University Press, Durham

6. Haraway DJ (2008) When species meet. University of Minnesota Press, Minneapolis

7. Foucault M (1970) The order of things: An archaeology of the human sciences. Pantheon, New York

8. Åsberg C (2018) Feminist posthumanities. In: Braidotti R, Hlavajova M (eds) Posthuman glossary. Bloomsbury Academic, London, pp 157-160

9. Descartes R (2002) Meditations on first philosophy in focus. Tweyman S (ed) Routledge, Milton Park

10. Spinoza B (1999) The ethics: Ethica ordine geometrico demonstrata. Transl. R.H.M. Elwes. Project Gutenberg, Champaign, Ill

11. Deleuze G (1992) Differenz und Wiederholung. Fink, München

12. Deleuze G, Guattari F (1987) A thousand plateaus: Capitalism and schizophrenia. University of Minnesota Press, Minneapolis

13. Barad K (2003) Agential realism: How material-discursive practices matter. Signs 28(3):803-831

14. Latour B (2005) Reassembling the social: An introduction to actor-network-theory. Oxford University Press, Oxford

15. Descola P (2013) Beyond nature and culture. University of Chicago Press, Chicago

16. Viveiros de Castro E (1998) Cosmological deixis and Amerindian perspectivism. J R Anthropol Inst 4(3):469-488

17. Åsberg C, Lykke N (2010) Feminist technoscience studies. European Journal of Women's Studies 17(4):299-305. https://doi.org/10.1177/1350506810377692

18. Kubes $\mathrm{T}$ (2019a) New materialist perspectives on sex robots: A feminist dystopia/utopia? Soc Sci 8(8):224. https://www.mdpi.com/2076-0760/8/8/224

19. Kubes T (2019b) Bypassing the uncanny valley: Postgender sex robots and robot sex beyond mimicry. In: Coeckelbergh M, Loh J (eds) Techno:Phil: Aktuelle Herausforderungen der Technikphilosophie. Metzler Verlag, Stuttgart, J.B, pp 59-73

20. Kubes T (2020) Queere Sexroboter : Eine neue Form des Begehrens? In: Bendel O (ed) Maschinenliebe: Liebespuppen und Sexroboter aus technischer, psychologischer und philosophischer Sicht. Springer Gabler, Wiesbaden, pp 163-183

21. Wajman J (2004) TechnoFeminism. Polity Press, Cambridge

22. Weber J (2006) From science and technology to feminist technoscience. In: Davis K, Evans M, Lorber J (eds) Handbook of gender and women's studies. Sage, London, pp 397-414

23. Seibt J (2018) Classifying forms and modes of coworking in the ontology of asymmetric social interactions (OASIS). In: Coeckelbergh M, Loh, J, Funk M, Seibt J, Nørskov M (eds.) Envisioning robots in society: Power, politics, and public space: Proceedings of robophilosophy 2018 / TREANSOR 2018. IOS Press, Amsterdam, pp 133-146

24. Marriott M (1976) Hindu transactions: Diversity without dualism. In: Kapferer B (ed) Transaction and meaning: Directions in the anthropology of exchange and symbolic behavior. Institute for the Study of Human Issues, Philadelphia, pp 109-142

25. Strathern M (1988) The gender of the gift: Problems with women and problems with society in Melanesia. University of California Press, Berkeley

26. Bird-David N (1999) "Animism" revisited: Personhood, environment, and relational epistemology. Current Anthropology 40, Supplement, February 1999, 67-91. https://www.journals.uchicago.edu/doi/pdf/10.1086/ 200061

27. Weber F (2001) Settings, interactions and things: A plea for multi-integrative ethnography. Ethnography 3(2001):475-499

28. Freud S (1955) A difficulty in the path of psychoanalysis. In: Strachey J (ed) The standard edition of the complete psychological works of Sigmund Freud, vol XVII. (1917-1919): An infantile neurosis and other works. The Hogarth Press and the Institute of Psychoanalysis, London, pp 135-144

29. Ingold T (2015) The life of lines. Routledge, Milton Park

30. Bennett J (2010) Vibrant matter: A political ecology of things. Duke University Press, Durham and London

31. Braidotti R (2013) The posthuman. Polity, Cambridge

32. Haraway DJ (1991) Simians, cyborgs, and women: The reinvention of nature. Routledge, New York

33. Hayles NK (1999) How we became posthuman: Virtual vodies in cybernetics, literature, and informatics. University of Chicago Press, Chicago

34. Latour B (1993) We have never been modern. Harvard University Press, Boston

35. Evernden N (1999) The natural alien: Humankind and environment. University of Toronto Press, Toronto

36. Agamben G (1998) Homo sacer: Sovereign power and bare life. Stanford University Press, Stanford

37. Ingold $T$ (2006) Rethinking the animate, re-animating thought. Ethnos 71:1, March 2006, 9-20

38. Ingold $T$ (2011) The perception of the environment: Essays in livelihood, dwelling and skill. Reissued with a new preface. Routledge, London

39. Tsing A (2013) More-than-human-sociality: A call for critical description. In: Hastrup K (ed) Anthropology and nature. Routledge, New York and London, pp 27-42

40. Tsing AL (2004) Friction: An ethnography of global connection. Princeton University Press, Princeton

41. Coeckelbergh M (2010) Robot rights? Towards a socialrelational justification of moral consideration. Ethics Inf Technol 12:209-221. https://doi.org/10.1007/ s10676-010-9235-5

42. Jacob F (1973) The logic of life: A history of heredity. Princeton University Press, Princeton

43. Toews R (2020) GPT-3 IS amazing - and overhyped. Forbes, July 19, 2020. https://www.forbes.com/sites/robtoews/2020/ 07/19/gpt-3-is-amazingand-overhyped/\#1584ab8f1b1c

44. Lacker K (2020) Giving GPT-3 a Turing test. Kevon Lacker's blog. July 6. 2020. https://lacker.io/ai/2020/07/06/giving-gpt3-a-turing-test.html, last accessed 15 July 2020 
45. Ferrando F (2019) Philosophical posthumanism. Bloomsbury, London

46. Tegmark M (2017). Life 3.0: Being human in the age of artificial intelligence. Alfred A. Knopf, New York

47. Bergson H (1911) Creative evolution. Macmillan, London

48. Ingold T (2016) Lines: A brief history. Routledge, Milton Park

49. Wagner R (1986) Symbols that stand for themselves. University of Chicago Press, Chicago

50. Knifka J (2016) On the significance of understanding in human-robot interaction. In: Nørskov M (ed) Social robots: Boundaries, potential, challenges. Routledge, London and New York, pp 4-18
51. Coyne L (2020) The ethics and ontology of synthetic biology: A neo-Aristotelian perspective. NanoEthics 14:43-55

52. Nietzsche F (1980) On the advantage and disadvantage of history for life. Hackett, Indianapolis

53. Frye N (1974) Fearful symmetry: A study of William Blake. Princeton University Press, Princeton

Publisher's Note Springer Nature remains neutral with regard to jurisdictional claims in published maps and institutional affiliations. 